\title{
Identification and Morphological Description of Xylocopa species (Xylocopidae: Hymenoptera) in North East of Libya
}

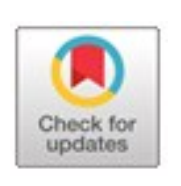

\author{
Marwa Y. H. Elmabruk and Ali A. Bataw* \\ Department of Zoology, Faculty of Science, Omar Almukhtar University Al-Bayda, Libya
}

Received: 25 August 2019/ Accepted: 30 December 2019

Doi: https://doi.org/10.54172/mjsc.v34i4.165

\begin{abstract}
The paper aimed to identify and describe the taxonomic morphological structure of Xylocopa species in North Eastern Libya. The samples were collected from different natural sites of Aljabal Alakhder region, identified, and morphological description and measurements of body length (in $\mathrm{cm}$ ) (From antennal base to apical of pygidium), front wings length, thorax, and abdomen width were conducted, four species of Xylocopa were identified and described morphologically, which includes Xylocopa (Koptortosoma) pubescens Spinola, 1838, Xylocopa (Proxylocopa) olivieri Lepeletier 1841, Xylocopa (Rhysoxylocopa), amedaei Lepeletier, 1841, Xylocopa iris (Christ, 1791). Our conclusion revealed that the investigated area was diverse with Xylocopa species and insists on the importance of descriptive study to supply taxonomic information.
\end{abstract}

Keywords: Xylocopa; Xylocopinae; Morphology; Identification; Libya

\section{INTRODUCTION}

Large carpenter bees, species of the genus Xylocopa Latreille, 1802, are considered as one of the important floral visitors and bee pollinators of flowering plants in many terrestrial ecosystems, including both agricultural plants and non-agricultural settings (Gerling et al., 1989; Hurd, 1963; Keasar, 2010; Mawdsley et al., 2016).

The genus Xylocopa includes about 450 species (Michener, 2007). The classification of subfamily Xylocopinae (Hymenoptera: Apidae) includes bees that are superficially very varied: in Israel, they are large and robust (13 to 33 $\mathrm{mm}$ long) Xylocopini as opposed to the small and slender ( 3 to $13 \mathrm{~mm}$ ) Allodapini, Ceratinini and Manueliini (Michener, 2007). Xylocopini (Xylocopa Latreille 1802: subgenera Copoxyla Maa, Ctenoxylocopa Michener, Koptortosoma Gribodo, Proxylocopa Hurd and Moure and Xylocopa Lepeletier), follow the higher classification of (Michener, 2007; Minckley, 1998).

Xylocopa generally, being black, metallic bluish or greenish-black, or purplish-blue.
Some males have yellowish areas on the face. Both sexes may have pale or yellowish pubescence on the thorax, legs, or abdomen, but these hairs are not as abundant or as intensely colored as in bumble bees. Large carpenter bees are readily distinguished from bumble bees primarily by the absence of pubescence on the dorsum of the abdomen, which is somewhat shiny (Michener, 2007). As noted by (Eardley, 1983), the taxonomy of species in this subgenus has been based largely on characteristics of body size and coloration, particularly the color of the pale pubescence on the mesosoma and metasoma of the females, which ranges from white to bright yellow. (Cockerell, 1908) used total body length and forewing length as diagnostic characters in a key to separate the different species.

Many of the Libyan endemic wild bee species are predominantly found on restricted mountain habitats Aljabale Alakhder (Zavattari, 1934). The area of Cyrenaica is considered to be one of the most densely populated areas of wild and cultivated flora. The studies of wild bees were limited to ancient studies from the Italian colonial period (Zavattari, 1934). 
The diversity and taxonomic description of Xylocopa species in the North East Libya region are still poorly known. The main objective of this research is to identify and describe the taxonomic morphological characteristics of some bee species in North East Libya to provide taxonomical information that facilitates species identifications.

\section{MATERIALS AND METHODS}

Study sites: The samples were collected from different natural sites of Aljabal alakhder region Eastern part of Libya (Cyrenaica): Elbaida, 32 $2^{\circ} 45^{\prime} 40.4^{\prime \prime} \mathrm{N} \quad 21^{\circ} 44^{\prime} 51.4^{\prime \prime} \mathrm{E}$ (619m) Cyrene $32^{\circ} 48^{\prime} 55.99^{\prime \prime N} 21^{\circ} 2^{\prime} 05.13^{\prime \prime E}(634 \mathrm{~m})$, Alwasita $32^{\circ} 51^{\prime} 08.83^{\prime \prime N} \quad 21^{\circ} 43^{\prime} 43.91^{\prime \prime E ~(336 ~}$ $\mathrm{m})$ and Sussa $32^{\circ} 53^{\prime} 47.86^{\prime \prime} \mathrm{N} 21^{\circ} 58^{\prime} 15.74^{\prime \prime E}$. $(15 \mathrm{~m})$ These locations characterized by coverage with dense wildflowers of Stachys tourneforti, Anchusa hybridia, Notobasis syriaca...etc, and flowers of cultivated plants such as almond, apple, and other vegetable.

\section{Collecting Bees}

In the Field: A biological survey for wild bees was conducted during different seasons (20142018), and collection was on a sunny day between 09:00 and 18:00 throughout the entire flowering period of the wild plants (February September). Bees were collected with sweep nets and aspirators. The collected bee specimens were kept in glass jars filled with paper tissues to avoid bee damage, and some drops of ethyl acetate to kill the bees. After the killing process, the specimens were stored in paper envelopes. Time and date of visited flowers were documented for each specimen. The coordinates were recorded for each site with a global positioning system (GPS) device.

In the Laboratory: Specimens were pinned and mounted, each specimen was labeled with an independent label containing the collecting time, date, and area of collection. All specimens were kept in wooden insect boxes supplied with foam plates for pinning and naphthalene balls to enable long storage without pest damage.

Identification of specimens: Identification was carried out by using available references (Hurd, 1963; Maa, 1970; Michener, 2007; Terzo \& Rasmont, 2014; Warncke, 1982), and all specimens confirmed by International Bees specialists.

\subsection{Morphological description}

The bee's description includes:

Measurements :Body length (in $\mathrm{cm}$ ) (From antennal base to apical of pygidium), front wings length, thorax and abdomen width.

Body color

Head: structure of vertex surface, compound eye, ocelli, clypeus, labrum, antenna, mouthparts, mandibles, genal area, facial fovea. Thorax: thorax structure, tegula, wing, legs structures

Abdomen: tergum, sternum and pygidial plate. Morphological terminology used in the descriptions of bees follows (Michener, 2007). Photographs of different morphological structures were taken by using a stereomicroscope equipped with an Olympus digital camera. All specimens were deposited in collection wood boxes in the entomology laboratory of the Zoology Department, Faculty of Sciences, Omar Almukhtar University.

\section{RESULTS}

Xylocopa (Koptortosoma) pubescens Spinola, 1838

$$
\text { =Xylocopa aestuans L., } 1758
$$

Examined material: $\bigcirc 1$ Albaida 15.7.2014, 4 Sussa 20.6.2018.

19-22 mm body length, body fairly robust, integument black or dark brown (Fig. 1). 


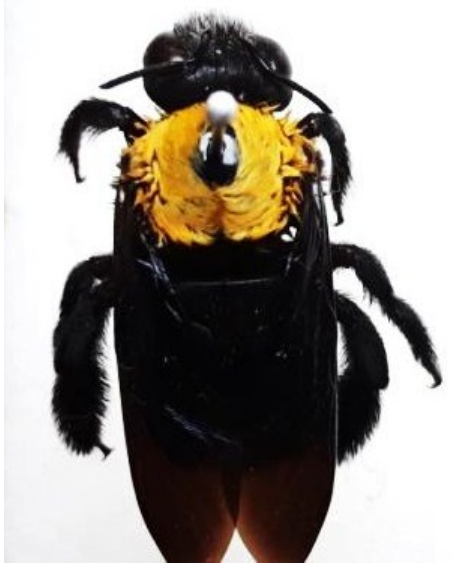

Figure (1). Adult of (ㅇ) Xylocopa pubescens.

Head: rounded and slightly narrower than the body, dense white setae, densely punctate, vertex curved to the inside with long black setae erected to the outside (Fig. 2).

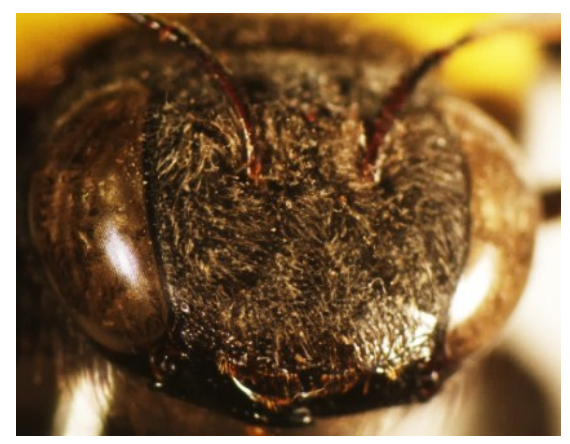

Figure (2). The head of (ㅇ) Xylocopa pubescens.

Compound eye: dark brown with small short scattered setae, dense long black setae between compound eyes, paraocular carina clear, genal area wide.

Ocelli: triangle shape, small, dark brown, the lateral ocelli less than the height level of compound eyes, the median ocellus aligned with frontal line (Fig. 3).

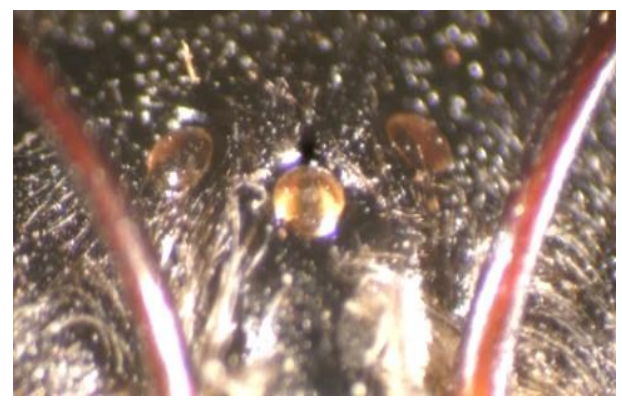

Figure (3). Ocelli of (ㅇ) Xylocopa pubescens.
Clypeus: black, the end of apical with two lateral extensions, long dark brown setae erected to down, densely punctate.

Mandibles: rectangular, elongated, black, bidentate at apex, apical tooth slightly longer than preapical tooth, black lope at the connected area with the malar area, outer ridge clear, little punctates (Fig. 4).

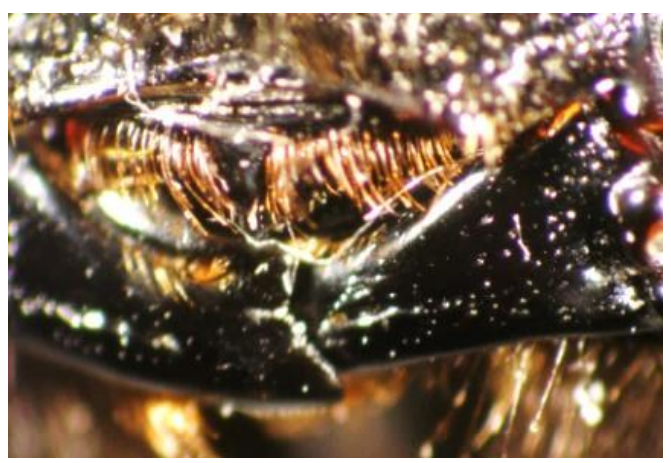

Figure (4). Mandible of () Xylocopa pubescens.

Labrum: short projection on a triangular shape, black.

Mouthparts: long, galea black at the base, dark brown at the apical, glossa light brown with dense short light brown setae (Fig.. 5).

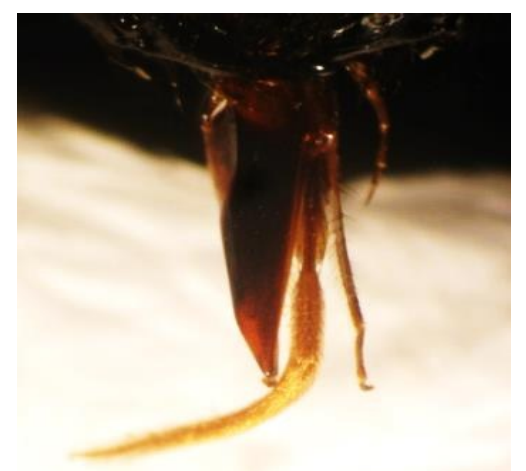

Figure (5). Mouthparts of () Xylocopa pubescens.

Antennae: twelve segments, antennal socket dark brown, scape long, rectangular, curved at the apical, dark brown to black, pedicel short, rounded, black, apical edge dark brown, flagellum ten segments, the first flagellomere longer than the rest of the other flagellomeres, narrower at the base, wider at the apical, black and apical edge light brown, the other tenth flagellomeres equal in the shape and size, light 
brown, the terminal flagellomere of antennae in sharp form (Fig. 6).

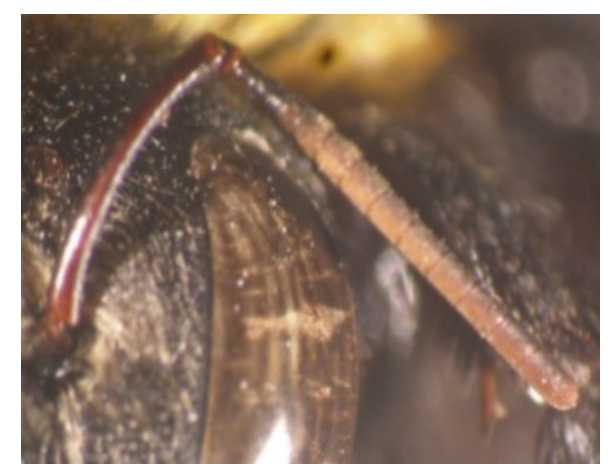

Figure (6). Antenna of (q) Xylocopa pubescens.

Thorax: width across thorax $4 \mathrm{~mm}$, prothorax larger than mesothorax and metathorax, black, dense long yellow setae cover the thorax surface (fig. 7), tegula clear, large, dark brown.

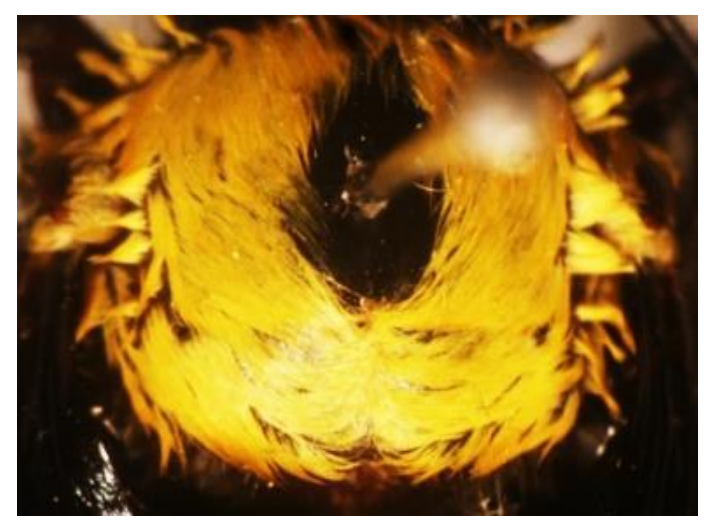

Figure (7). Thorax of (ㅇ) Xylocopa pubescens.

Wings: forewings length $6 \mathrm{~mm}$, dark brown, the veins darker brown, marginal cell long and wider at the middle, extended along the edge of the wing, the apical of marginal cell not jointed with costa vein, three submarginal cells, $3 \mathrm{smc}$ larger than $1 \mathrm{smc}$ and $2 \mathrm{smc}, 2 \mathrm{smc}$ smaller than $1 \mathrm{smc}$ and $3 \mathrm{smc}$, vein Rs ( $2^{\text {nd }}$ abscissa) curved, vein $1 \mathrm{rs}-\mathrm{m}$ with the same line vein $1 \mathrm{~m}-\mathrm{cu}$, vein $2 \mathrm{rs}-\mathrm{m}$ curved outward, vein $2 \mathrm{~m}$-cu meets median vein opposite third submarginal cell, basal vein straight, the lower end meeting the longitudinal vein at an acute angle (fig. 8a), the jugal lobe of hindwing is short, less than half the length of vannal lobe, and not nearly reaching the vein closing the cubital cell (Fig. $8 b)$.

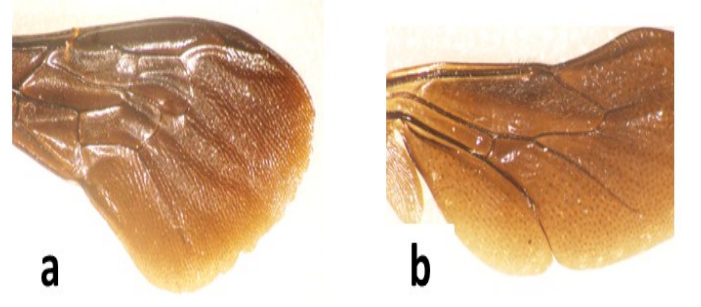

Figure (8). a- forewing, b- hindwing of (ㅇ) Xylocopa pubescens.

Legs: coxa elongated, triangular, dark brown with dense short black setae, trochanter rectangular, narrower at the base, wider at the apical, dark brown with long black setae, femur wider at the base, narrower at the apical, dark brown with dense long black setae erected downwards, tibia narrower at the base, wider at the apical, dark brown with dense long black setae, tibial spur ciliated from each side, long, black, forelegs and midlegs with one tibial spur (fig. 9a), hind legs with two tibial spurs, tibial spine one each leg, tarsus five segments in each leg, basitarsus longer than mediotarsus and distitarsus, dark brown with dense long black setae erected downwards, mediotarsus three segments equal in the shape and size, dark brown with little long black robust setae erected downwards at the apical, distitarsus is longer than mediotarsus, narrower at the base, wider at the apical, dark brown with little black setae (Fig. 9b).
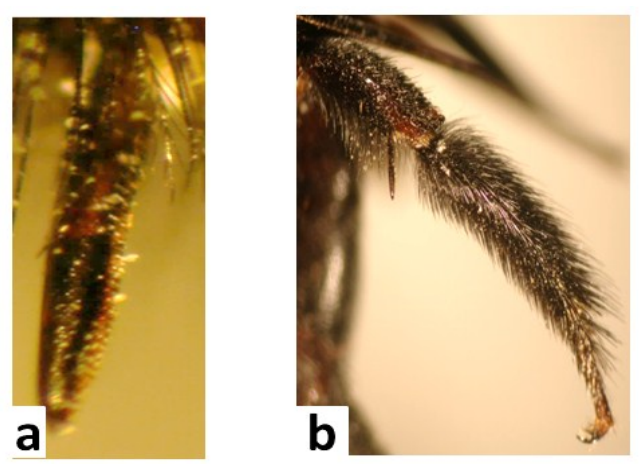

Figure (9). a-Tibial spur, b-Midleg of (ㅇ) Xylocopa pubescens.

Pair of elongated tarsal claws, branched at apical, the lateral longer than the internal one, 
the base dark brown, apical black, arolium with short yellow setae (Fig. 10).

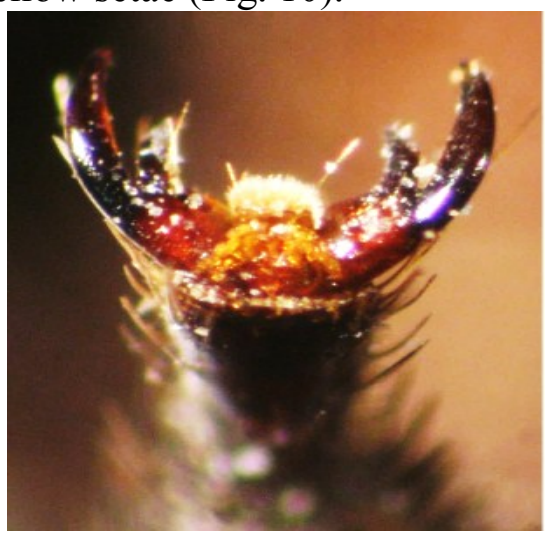

Figure (10). Tarsal claws of () Xylocopa pubescens.

Abdomen: width across abdomen $8 \mathrm{~mm}$, six segments, black with dark brown color bands at apical edges, densely punctate, tergum II wider than the rest of the other terga, tergum VI triangle-shaped, narrower than the rest of the other terga (fig. 11a), the pygidial plate black, relatively narrow and extend across tergum VI with dense long dark brown robust setae erected downwards, dense long black setae at the edges, sternum the base dark brown, apical black, dense black setae at the apical edge of each sternum, sterna I to III has a meeting area in the middle (Fig.11b).
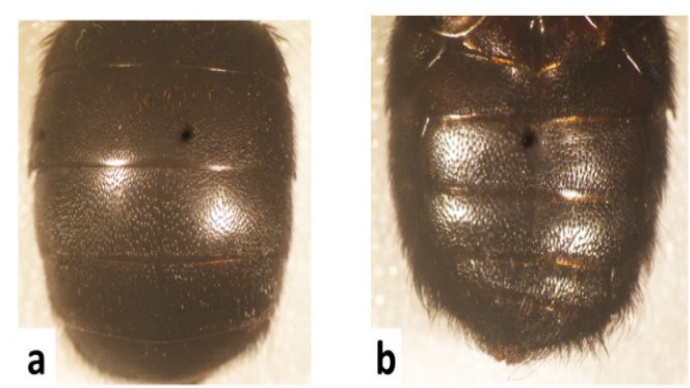

Figure (11). a- Tergum, b- Sternum of (ㅇ) Xylocopa pubescens.

\section{Xylocopa (Proxylocopa) olivieri lepeletier} 1841

Examined material: $\widehat{\jmath} 1$ Albaida 15.7.2014.

$16 \mathrm{~mm}$ body length (fig. 12).

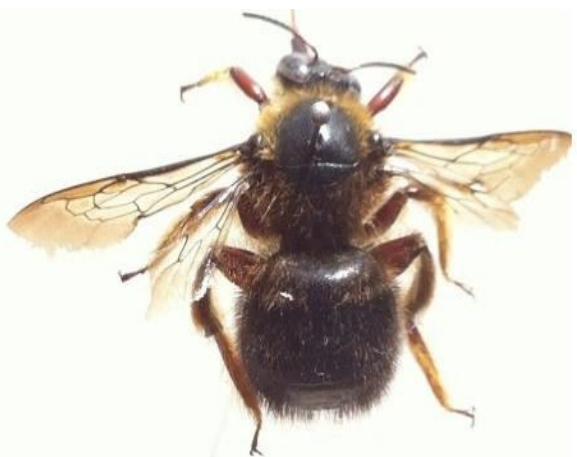

Figure (12). Adult of (ð) Xylocopa olivieri.

Head: triangular, narrower than the body, black, densely punctate, vertex simple, curved to the inside with long light brown setae erected to the outside.

Compound eyes: light brown and occupy most of the head, dense long light brown setae between compound eyes, paraocular carina clear, genal area narrow.

Ocelli: triangle-shaped, dark brown, the median ocellus bigger in the size than the lateral ocelli, the lateral ocelli less than the height level of compound eyes, the median ocellus with frontal line (Fig. 13).

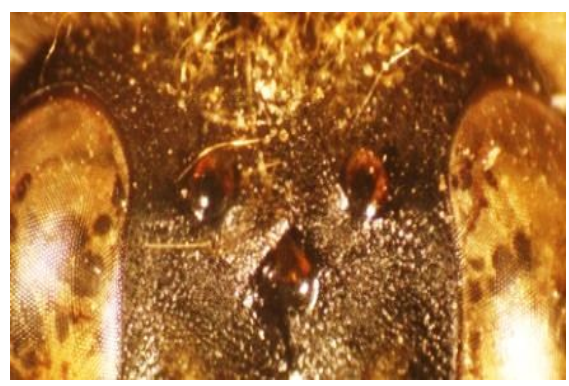

Figure (13). Ocelli of (ð) Xylocopa olivieri.

Clypeus: clear, reddish brown, densely punctate (Fig. 14).

paraocular lobe: clear, dark brown.

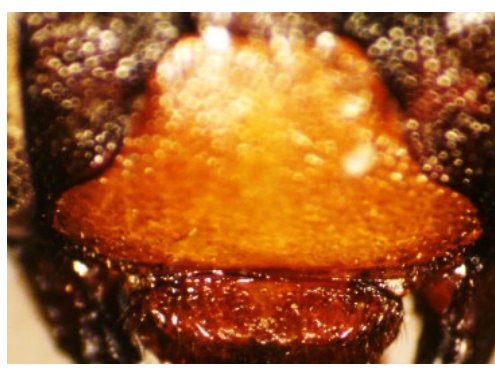

Figure (14). Clumps' of (ð) Xylocopa olivieri. 
Mandibles: rectangular, dark brown, wider at the base, narrower at the apical, bidentate at apex, apical tooth longer than the preapical tooth, two condylar ridges clear, densely punctate especially at the base (Fig. 15).

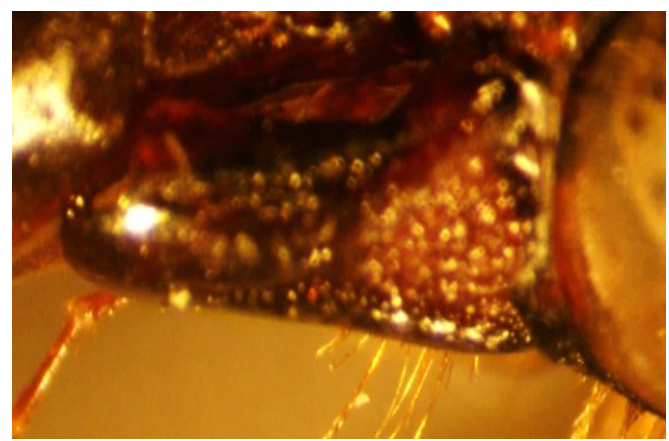

Figure (15). Mandible of (ð) Xylocopa olivieri.

Labrum: rectangular, dark brown, densely punctate.

Mouthparts: long, galea dark brown, glossa light brown with dense short light brown setae erected to down (Fig. 16).

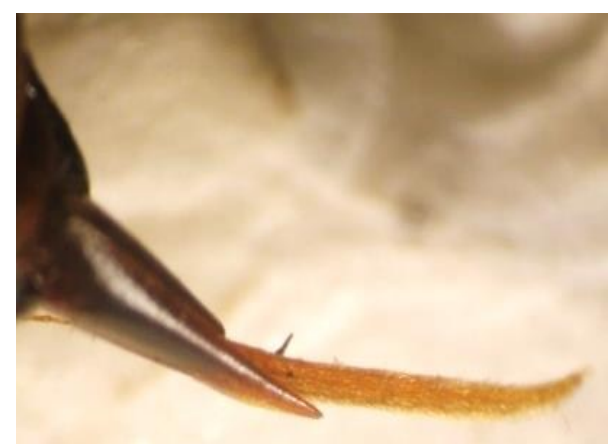

Figure (16). Mouthparts of ( $\overbrace{}^{\Uparrow})$ Xylocopa olivieri.

Antennae: thirteen segments, dark brown, scape long, rectangular, curved at the apical, pedicel short, rounded, flagellum eleven segments, the first flagellomere longer than the rest of the other flagellomeres, narrower at the base, wider at the apical, the other tenth flagellomeres equal in the shape and size, the terminal flagellomere of antennae is rounded form (Fig. 17).

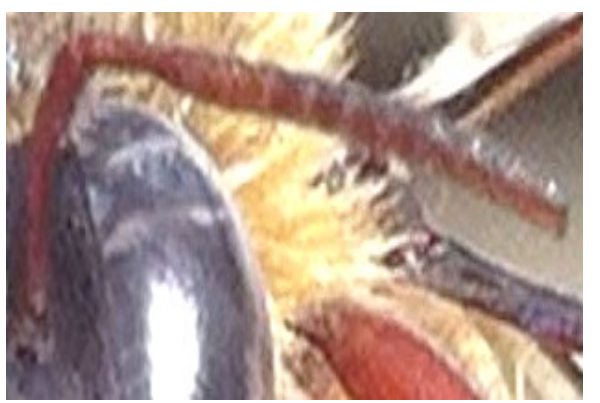

Figure (17). Antenna of (ఏ) Xylocopa olivieri.

Thorax: width across thorax 8-9 mm, prothorax larger than mesothorax and metathorax, black, densely punctate, dense long yellow setae (Fig. 18), tegula clear, large, dark brown.

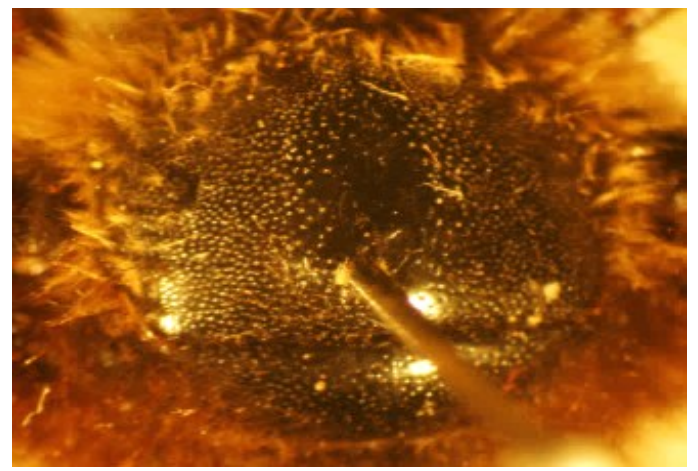

Figure (18). Thorax of (ð) Xylocopa olivieri.

Wings: forewings length $14 \mathrm{~mm}$, transparent brown, the veins dark brown, vein Sc+R black, marginal cell long and narrow, marginal cell darker than the rest of the wing, the apical of marginal cell not jointed with costa vein, three submarginal cells, $3 \mathrm{smc}$ larger than $1 \mathrm{smc}$ and $2 \mathrm{smc}$, $2 \mathrm{smc}$ smaller than $1 \mathrm{smc}$ and $3 \mathrm{smc}$, vein Rs ( $2^{\text {nd }}$ abscissa) curved, vein 1rs- $m$ with the same line vein $1 \mathrm{~m}-\mathrm{cu}$, vein $2 \mathrm{rs}-\mathrm{m}$ curved outward, vein $2 \mathrm{~m}$-cu meets median vein opposite third submarginal cell, basal vein slightly and evenly arched, the lower end meeting the longitudinal vein at an acute angle (fig. 19), the jugal lobe of hindwing is short, less than half the length of the vannal lobe, and not nearly reaching the vein closing the cubital cell. 


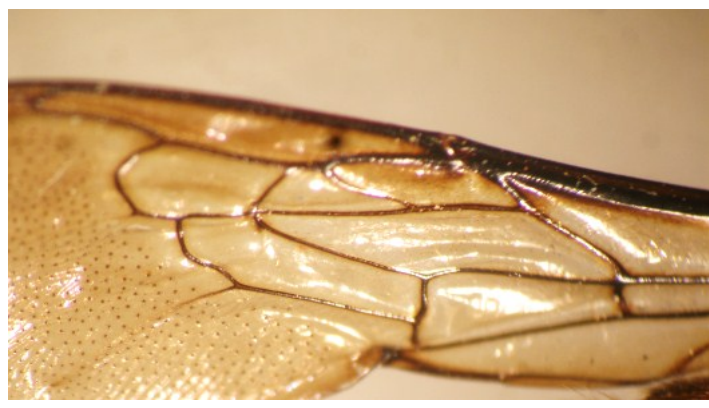

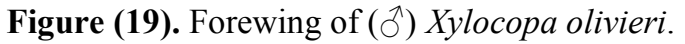

Legs: coxa triangle, light brown with little long yellow setae, trochanter narrower at the base, wider at the apical, light brown with little long yellow setae, fumer wider at the base, narrower at the apical, dark brown with long yellow setae erected downwards, tibia long, narrower at the base, wider at the apical, light brown with dense long yellow setae erected downwards, tibial spur one on each leg, ciliated, pointed at the apical, dark brown, tibial spine one on each leg, tarsus five segments on each leg, basitarsus longer than mediotarsus and distitarsus, dark brown with dense long yellow setae, mediotarsus three segments equal in the shape and size with little long yellow robust setae erected downwards at the apical, distitarsus longer than mediotarsus, narrower at the base, wider at the apical, dark brown with little short yellow robust setae erected downwards at the apical (Fig. 20).

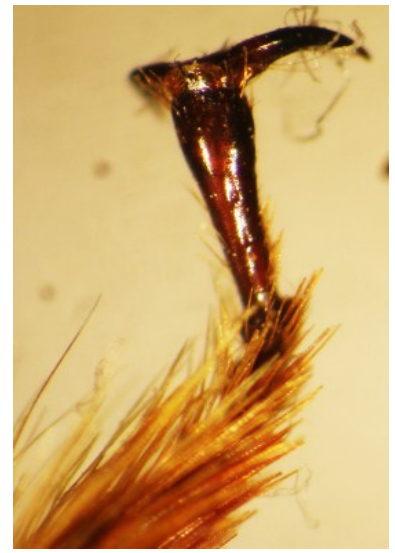

Figure (20). Distitarsus of (ठ઼) Xylocopa olivieri.

Pair of elongated tarsal claws branched at apical, the lateral longer than the internal one, the base dark brown, apical black, arolium with short yellow setae (Fig. 21). setae (Fig. 21).

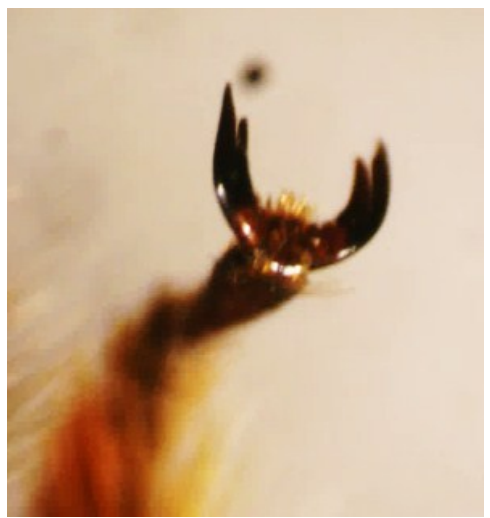

Figure (21). Tarsal claws of (ठ̊) Xylocopa olivieri.

Abdomen: width across abdomen $9 \mathrm{~mm}$, seven segments, black with dark brown color bands at apical edges, dense long yellow setae, densely punctate, tergum II is wider than the rest of the other terga, tergum VII is a semi-rounded shape, narrower than the rest of the other terga, edges with bands of dense yellow setae (Fig.. 22a), sternum each sternum has a little curve at the apical with a bond of dense long light brown setae (Fig. 22b).
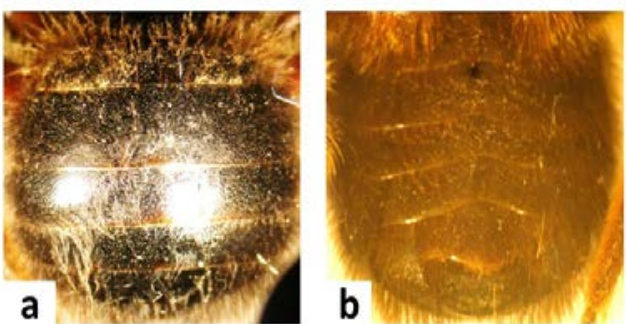

Figure (22). a- Tergum, b- Sternum of (ठ઼) Xylocopa olivieri.

\section{Xylocopa (Proxylocopa) olivieri lepeletier 1841}

Examined material: $\$ 1$ Albaida 20.7.2014.

$24 \mathrm{~mm}$ body length (Fig. 23).

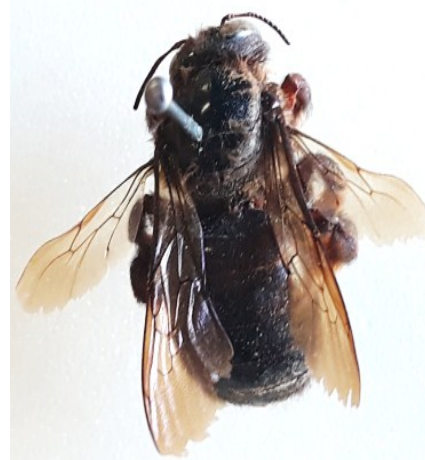


Figure (23). Adult of (q) Xylocopa olivieri.

Head: rounded and slightly narrower than the body, black, densely punctate, vertex simple, curved to the inside with dense long light brown setae erected to the outside (fig. 24).

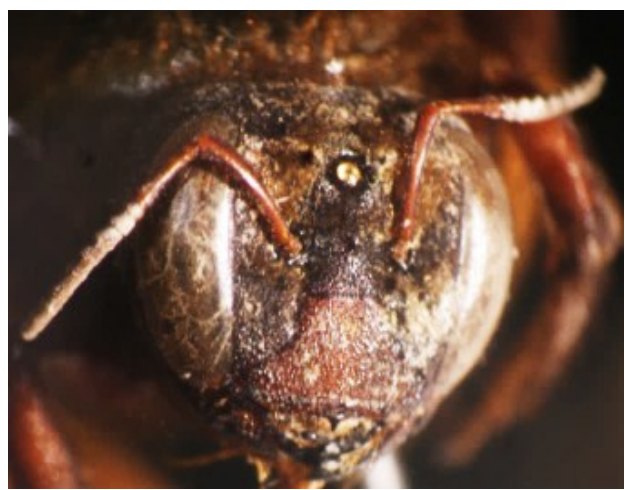

Figure (24). The head of (q) Xylocopa olivieri.

Compound eyes: light brown, dense long light brown setae between compound eyes, paraocular carina is clear, genal area is wide.

Ocelli: triangle shape, bright brown, the lateral ocelli is less than the height level of compound eyes, median ocellus aligned with frontal line.

Clypeus: dark brown, the end of apical is thick, small long light brown setae, densely punctate.

Paraocular lobe: clear, dark brown.

Mandibles: rectangular, dark brown at the base, black at the apical, bidentate at the apex, apical tooth longer than the preapical tooth, sharp teeth, dark brown lope at the connecting area with the malar area, malar area dark brown, outer ridge and condylar ridge clear with little long light brown setae, acetabular groove clear, outer groove clear, condylar groove clear (Fig. 25).

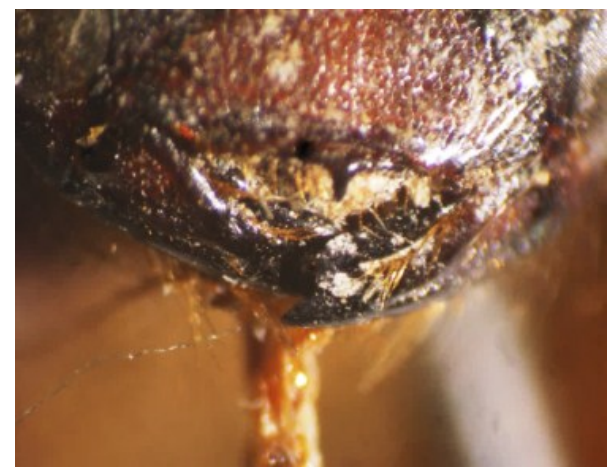

Figure (25). Mandible of (ㅇ) Xylocopa olivieri.

Labrum: short projection on triangular shape, black.

Mouthparts: long, galea dark brown, glossa light brown with little short light brown setae erected downwards (Fig. 26).

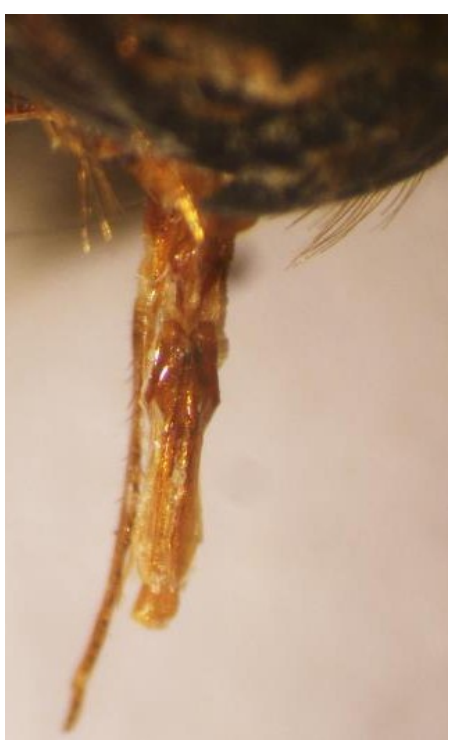

Figure (26). Mouthparts of (ㅇ) Xylocopa olivieri.

Antennae: twelve segments, dark brown, antennal socket dark brown, scape long, curved at the apical, narrower at the base, wider at the apical, pedicel short, rounded, flagellum ten segments, the first flagellomere longer than the rest of the other flagellomeres, narrower at the base, wider at the apical, the other ninth flagellomeres equal in shape and size, the terminal flagellomere of antennae is in a sharp form (Fig. 27).

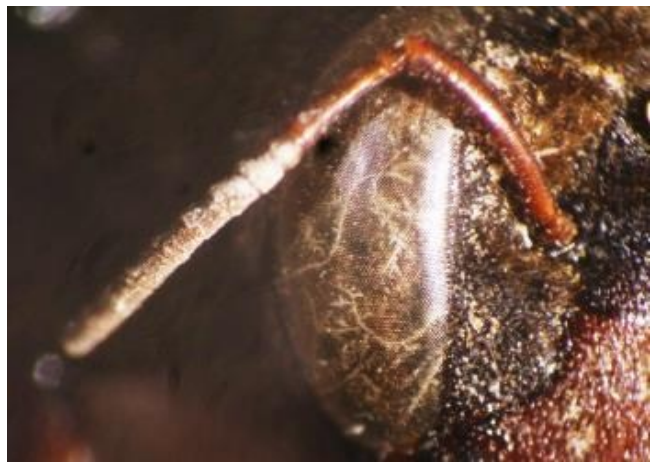

Figure (27). Antenna of () Xylocopa olivieri.

Thorax: width across thorax $8 \mathrm{~mm}$, prothorax larger than mesothorax and metathorax, black, 
densely punctate, dense long light brown setae, tegula clear, large, dark brown (Fig. 28).

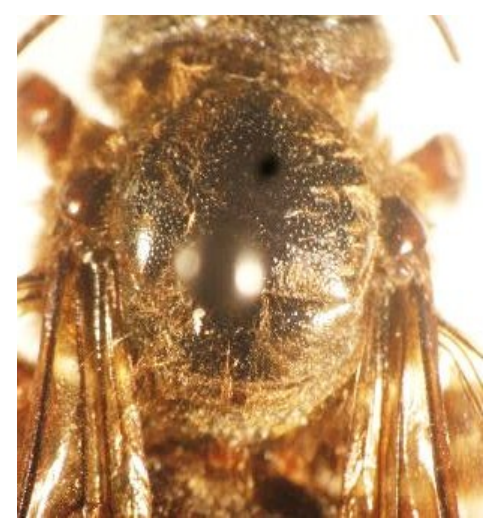

Figure (28). Thorax of (†) Xylocopa olivieri.

Wings: forewings length $17 \mathrm{~mm}$, transparent brown, the veins dark brown, vein Sc+R black, marginal cell long and narrow, marginal cell darker than the rest of the wing, the apical of the marginal cell is not jointed with costa vein, three submarginal cells, $3 \mathrm{smc}$ larger than $1 \mathrm{smc}$ and $2 \mathrm{smc}$, vein $1 \mathrm{rs}-\mathrm{m}$ with the same line vein $1 \mathrm{~m}-\mathrm{cu}$, vein $2 \mathrm{rs}-\mathrm{m}$ curved outward, vein $2 \mathrm{~m}$-cu meets median vein opposite the third submarginal cell, basal vein straight and evenly arched, the lower end meeting the longitudinal vein at an acute angle (fig. 29a), the jugal lobe of hindwing is very short, much less than half the length of the vannal lobe, and not reaching anywhere near as far as the vein closing the cubital cell (fig. 29b).
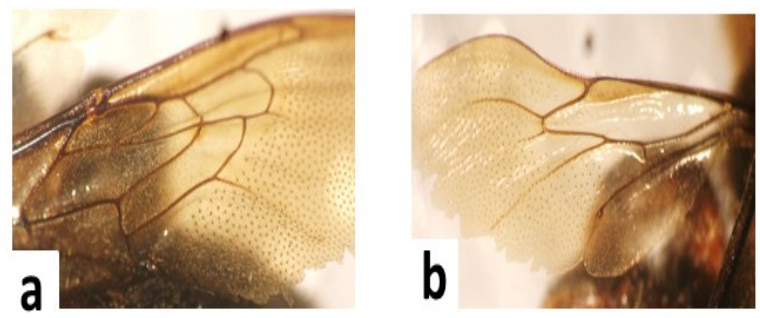

Figure (29). a- Forewing, b- Hindwing of (†) Xylocopa olivieri.

Legs: coxa triangular, dark brown with dense long dark brown setae, trochanter rectangular, narrower at the base, wider at the apical, dark brown with dense dark brown setae at the edges, Fumer wider at the base, narrower at the apical, dark brown with long black setae erected downwards, tibia rectangular, wider at the base, narrower at the apical, dark brown with dense long black setae erected downwards, tibial spur one on each leg, ciliated from each side, dark brown, tibial spur of forelegs short, tibial spur of midlegs and hind legs long, tibial spine one on each leg, tarsus five segments on each leg, basitarsus longer than mediotarsus and distitarsus, dark brown with dense long dark brown setae erected downwards of forelegs, dark brown with dense long reddish brown setae erected downwards of midlegs and hind legs, mediotarsus three segments equal in shape and size, dark brown with little long reddish brown robust setae erected downwards at the apical, distitarsus longer than mediotarsus, narrower at the base, wider at the apical, dark brown with little short reddish brown robust setae erected downwards at the apical (Fig. 30), tarsus of hind legs with dense long reddish brown setae more than the forelegs and midlegs.

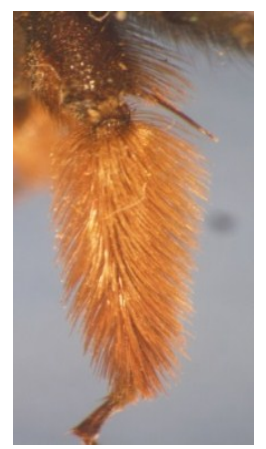

Figure (30). Hind leg of (ㅇ) Xylocopa olivieri.

Pair of elongated tarsal claws, branched at apical, the lateral longer than the internal one, the base dark brown, apical black, arolium with short yellow setae (Fig. 31).

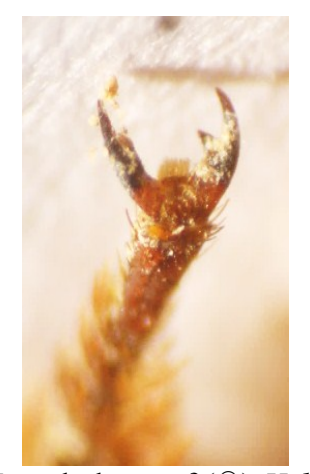

Figure (31). Tarsal claws of () Xylocopa olivieri. 
Abdomen: width across abdomen $10 \mathrm{~mm}$, six segments, the base black, apical dark brown, each tergum with dense long light brown setae, terga from $\mathrm{I}$ to $\mathrm{V}$ equal in the shape and size, tergum VI triangle shape, narrower than the rest of the other terga, dense long dark brown setae at the edges (Fig. 32a), sternum dark brown with dense long reddish-brown setae erected downwards especially at the edge of each sternum (Fig. 32b ).

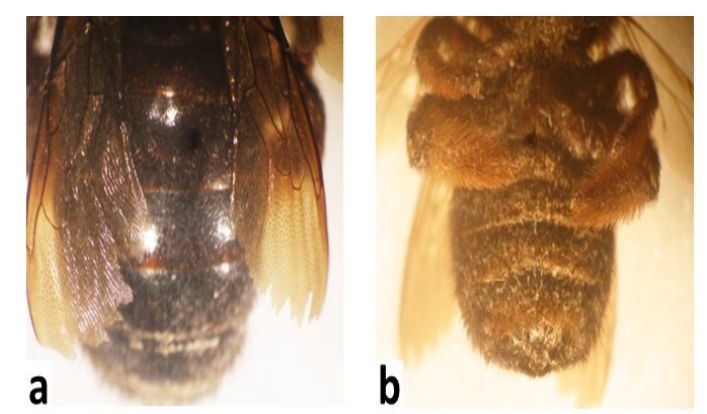

Figure (32). a- Tergum, b- Sternum of (q) Xylocopa olivieri.

\section{Xylocopa (Rhysoxylocopa) amedaei}

Lepeletier, 1841

Examined material: $q 1$ Albaida 15.6.2012.

$20 \mathrm{~mm}$ body length (Fig. 33).

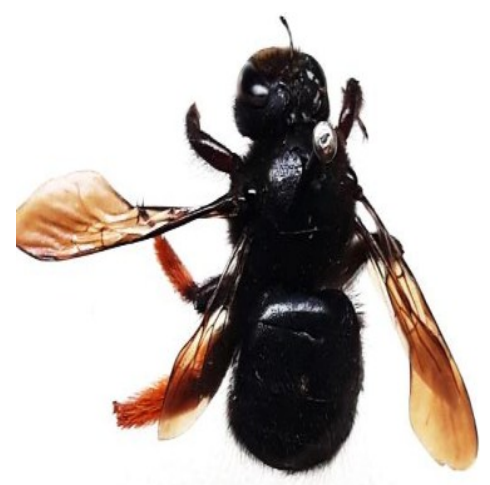

Figure (33). Adult of (ㅇ) Xylocopa amedaei .

Head: rounded and slightly narrower than the body, black, densely punctate, vertex simple and curved to the inside with dense long black setae erected to the outside.

Compound eyes: bright black, dense short light brown setae between compound eyes, paraocular carina clear, genal area is wide.
Ocelli: triangle shape, dark brown, the lateral ocelli less than the height level of compound eyes, median ocellus aligned with frontal line.

Clypeus: dark brown, the end of apical with two lateral extensions curved to the inside, densely punctate, dense long dark brown setae erected downwards.

Mandibles: rectangular, wider at the base, narrower at the apical, bidentate at apex, apical tooth longer than preapical tooth, black with black lope at the connecting area with the malar area, outer groove clear, densely punctate especially at the base (fig. 34).

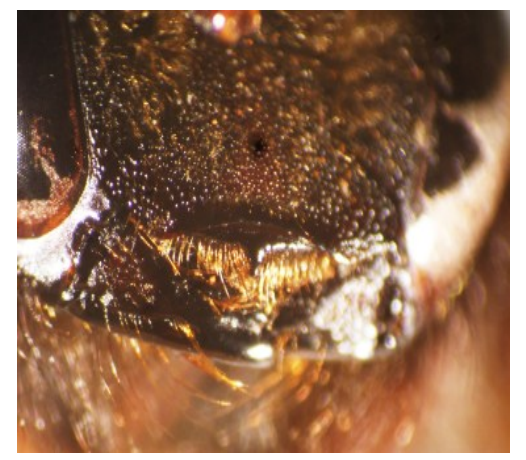

Figure (34). Mandible of (ㅇ) Xylocopa amedaei.

Labrum: short projection on triangular shape, black,

Mouthparts: long, galea dark brown, glossa light brown with long light brown setae erected downwards.

Antennae: twelve segments, dark brown, antennal socket dark brown, scape long, curved at the apical, pedicel short, rounded, flagellum ten segments, the first flagellomere longer than the rest of the other flagellomeres, narrower at the base, wider at the apical, the other nine flagellomeres equal in shape and size, the terminal flagellomere of antennae in a sharp form (Fig. 35).

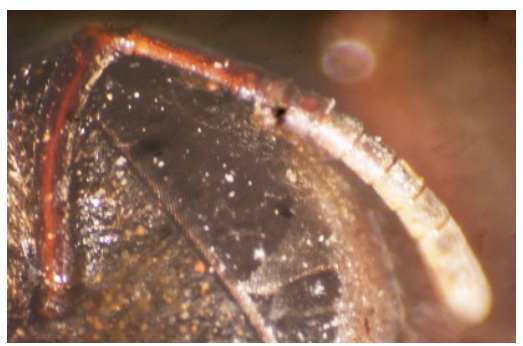


Figure (35). Antennae of ( $(+)$ Xylocopa amedaei. Thorax: width across thorax $5 \mathrm{~mm}$, prothorax larger than mesothorax and metathorax, black, dense long light brown setae, densely punctate, tegula clear, large, black (Fig. 36).

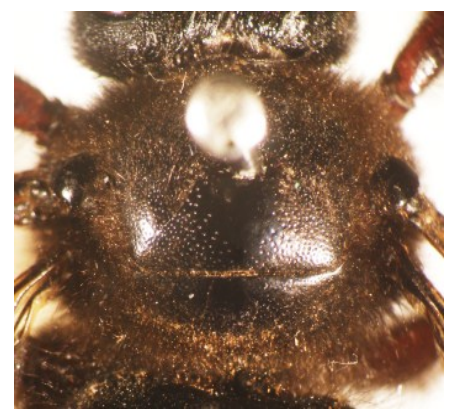

Figure (36). Thorax of (q) Xylocopa amedaei.

Wings: forewings length $17 \mathrm{~mm}$, light brown, the veins dark brown, vein $\mathrm{Sc}+\mathrm{R}$ black, marginal cell long and narrow, marginal cell darker than the rest of the wing, the apical of marginal cell not jointed with costa vein, three submarginal cells, $3 \mathrm{smc}$ longer than $1 \mathrm{smc}$ and $2 \mathrm{smc}$, vein $1 \mathrm{rs}-\mathrm{m}$ with the same line vein $1 \mathrm{~m}$ $\mathrm{cu}$, vein $2 \mathrm{rs}-\mathrm{m}$ curved outward, vein $2 \mathrm{~m}-\mathrm{cu}$ meets median vein opposite third submarginal cell, basal vein straight, the lower end meeting the longitudinal vein at an acute angle (Fig. $37 a)$, jugal lobe of hindwing very short, much less than half the length of the vannal lobe, and not reaching anywhere near as far as vein closing cubital cell (Fig. 37b).
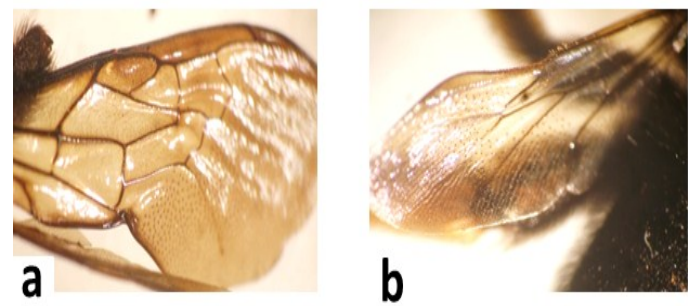

Figure (37). a- Forewing, b- Hindwing of Xylocopa amedaei.

Legs: trochanter narrower at the base, wider at the apical, dark brown with dense black setae at the edges, fumer long, rectangular, dark brown with dense long black setae erected downwards, tibia elongated, wide, dark brown with dense long black setae erected downwards of forelegs and midlegs, dark brown with dense long reddish brown setae erected downwards of hind legs, tibial spur ciliated at inner edge, sharp at the outer edge, dark brown, forelegs with one tibial spur, short, midlegs with one tibial spur, long, hind legs with two tibial spurs, long, tibial spine one each leg, tarsus five segments on each leg, basitarsus longer than mediotarsus and distitarsus, dark brown with dense long black robust setae erected downwards of forelegs, dense long reddish brown robust setae erected downwards of midlegs and hind legs, mediotarsus three segments equal in shape and size, dark brown with little reddish-brown robust setae at the apical, distitarsus longer than mediotarsus, narrower at the base, wider at the apical, dark brown with little short reddish-brown robust setae erected downwards at the apical (Fig. 38).

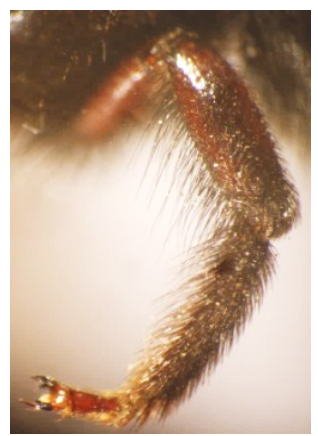

Figure (38). Midleg of () Xylocopa amedaei. Pair of elongated tarsal claws, branched at apical, the lateral longer than the internal one, the base dark brown, apical black, arolium with short yellow setae (Fig. 39)

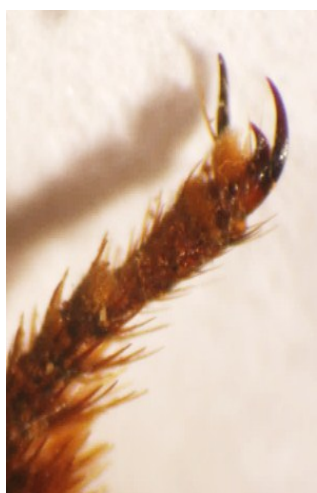

Figure (39). Tarsal claws of () Xylocopa amedaei.

Abdomen: width across abdomen $5 \mathrm{~mm}$, six segments, black, dense black setae, tergum II wider than the rest of the other terga, tergum VI semi-rounded shape, narrower than the rest of the other terga, sternum black with dense 
long light brown setae erected downwards (Fig. 40a), sternum I narrower at the apical, dense long black setae at the edges (Fig. 40b).
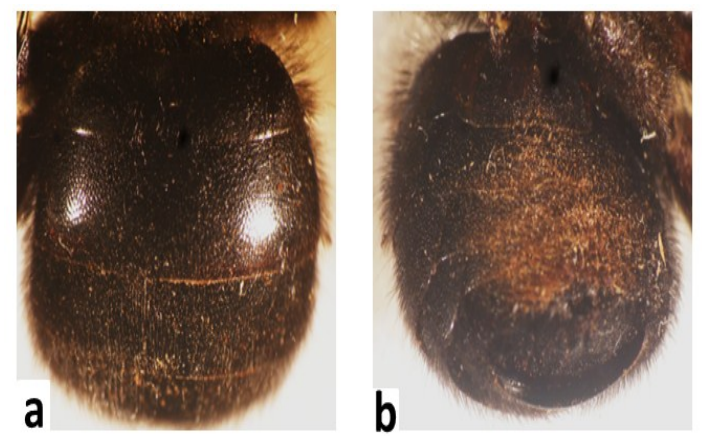

Figure (40). a- Tergum, b- Sternum of (q) Xylocopa amedaei.

\section{Xylocopa (Copoxyla) iris}

(Christ, 1791) $q$

Examined material: $\circ 2$ Albaida 29.6.2018, 1 Albaida 3.7.2018, 13 Albaida 20.7.2018. $18 \mathrm{~mm}$ body length (Fig. 41).

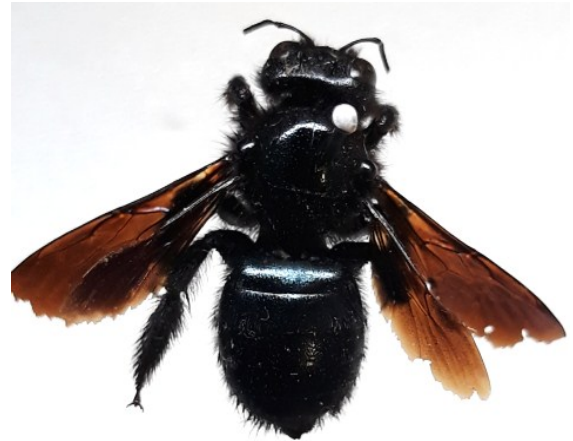

Figure (41). Adult of (q) Xylocopa iris.

Head: rounded and slightly narrower than the body, black, densely punctate, vertex simple curved to the inside with little long black setae erected to outside (Fig. 42).

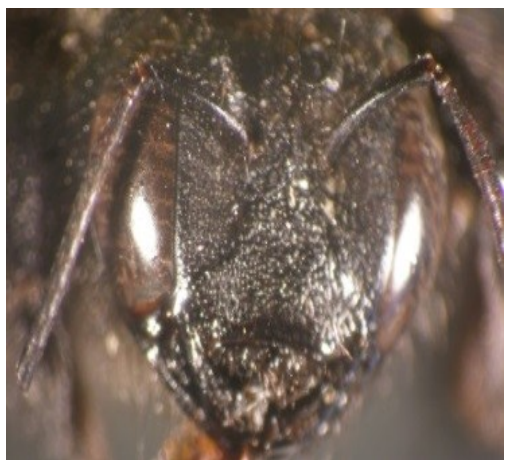

Figure (42). The head of Xylocopa iris.
Compound eyes: dark brown with short scattered light brown setae, dense long black setae between compound eyes, paraocular carina clear, genal area is wide.

Ocelli: triangle shape, dark brown, the median ocellus bigger in size than the lateral ocelli, the lateral ocelli less than the height level of compound eyes, the median ocellus aligned with frontal line (Fig. 43).

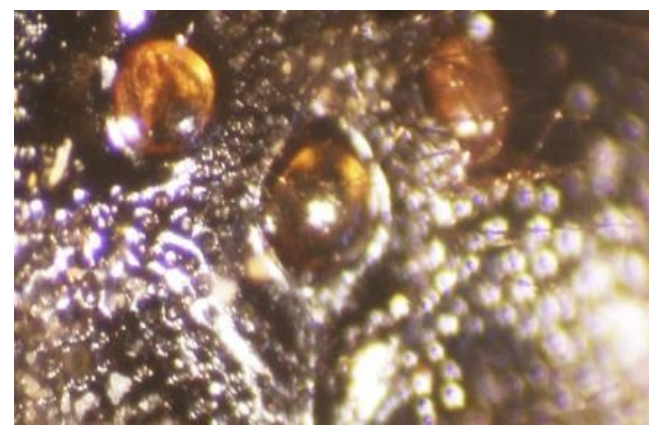

Figure (43). Ocelli of () Xylocopa iris.

Clypeus: black, the end of apical thick, dark brown, black projection at the middle of the base, densely punctate, dense long black setae.

Mandibles: rectangular, tridentate at apex, black with black lope at the connecting area with the malar area, acetabular groove clear, outer groove clear, condylar groove clear, densely punctate (Fig. 44).

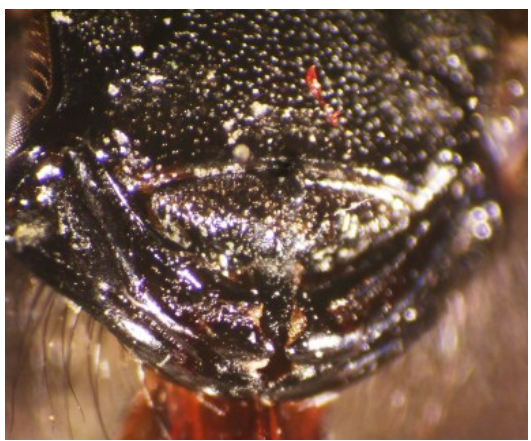

Figure (44). Mandible of (q) Xylocopa iris.

Labrum: semi-rounded shape with triangular extension at the middle, black.

Mouthparts: long, galea dark brown to black, glossa light brown with dense light brown setae. 
Antennae: twelve segments, antennal socket dark brown, scape long, rectangular, dark brown, pedicel short, rounded, dark brown, flagellum ten segments, black, the first flagellomere narrower at the base, wider at the apical, longer than the rest of the other flagellomeres, the other nine flagellomeres equal in shape and size, the terminal flagellomere of antennae in a sharp form (Fig. 45).

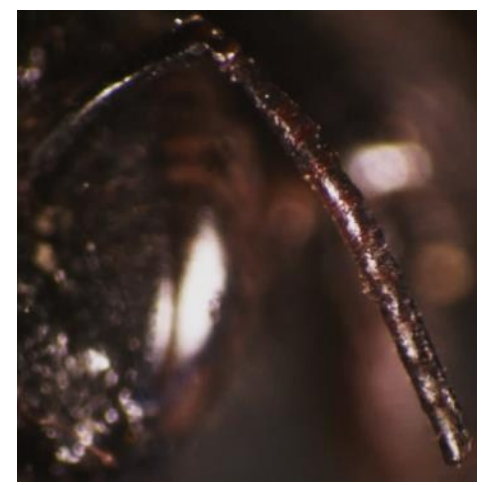

Figure (45). Antenna of ( $(+)$ Xylocopa iris.

Thorax: width across thorax $5 \mathrm{~mm}$, prothorax larger than mesothorax and metathorax, black, mesoscutal line clear, dense long black setae, densely punctate, tegula clear, large, black.

Wings: forewings length $14 \mathrm{~mm}$, dark brown, the veins light brown, vein $\mathrm{Sc}+\mathrm{R}$ black, marginal cell long and narrow, the apical of marginal cell not jointed with costa vein, three submarginal cells, 2smc narrow, triangular, $3 \mathrm{smc}$ wider than $1 \mathrm{smc}$ and $2 \mathrm{smc}$, vein $1 \mathrm{rs}-\mathrm{m}$ with the same line vein $1 \mathrm{~m}-\mathrm{cu}$, vein $2 \mathrm{rs}-\mathrm{m}$ curved outward, vein $2 \mathrm{~m}$-cu meets median vein opposite third submarginal cell, basal vein slightly curved, the lower end meeting the longitudinal vein at an acute angle (Fig. 46a), jugal lobe of hindwing short, less than half the length of the vannal lobe, and not nearly reaching vein closing the cubital cell (Fig.46b).
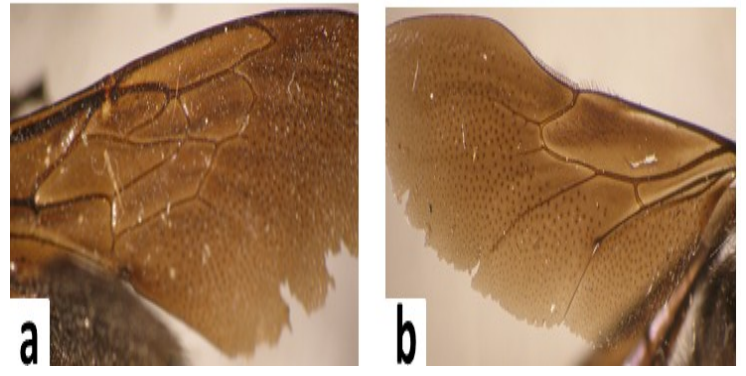

Figure (46). a- Forewing, b- Hindwing of () Xylocopa iris.

Legs: coxa triangular, black with little black setae, trochanter rectangular, narrower at the base, wider at the apical, black with little long black setae, femur wider at the base, narrower at the apical, black with dense long black setae erected downwards, tibia long, rectangular, black with dense long black setae erected downwards, tibial spur ciliated at inner edge, sharp at the outer edge, dark brown, forelegs with one tibial spur, short, midlegs with one tibial spur, long (Fig. 47a), hind legs with two tibial spur, long (Fig. 47b), tibial spine one on each leg, tarsus five segments on each leg, basitarsus longer than mediotarsus and distitarsus, black with dense long black robust setae, mediotarsus three segments equal in shape and size, dark brown with little long black setae at the apical, distitarsus longer than mediotarsus, narrower at the base, wider at the apical, dark brown with little black robust setae and dense short yellow setae at the apical.
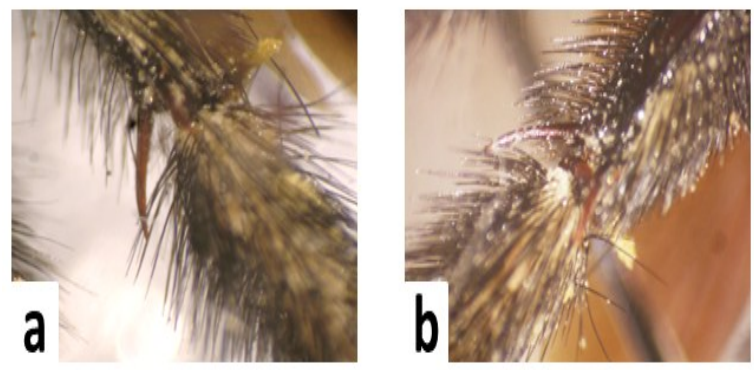

Figure (47). a-Tibial spur of midleg, b- Tibial spur of hind leg of (ㅇ) Xylocopa iris.

Pair of elongated tarsal claws, branched at apical, the lateral longer than the internal one, the base dark brown, apical black, arolium with short yellow setae (Fig. 48). 


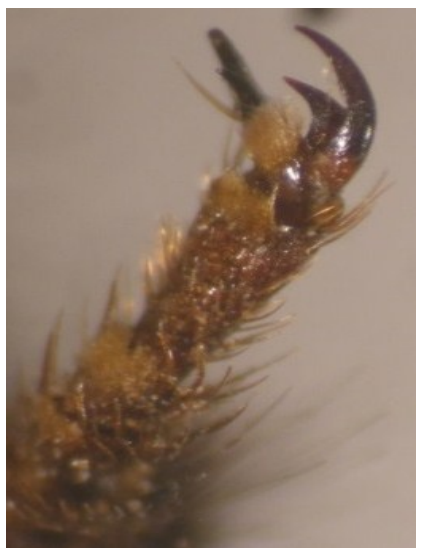

Figure (48). Tarsal claws of (q) Xylocopa iris.

Abdomen: width across abdomen $7 \mathrm{~mm}$, six segments, black, densely punctate, dense long black setae erected downwards, tergum II wider than the rest of the other terga, tergum VI triangle shape, narrower than the rest of the other terga, dense short black setae at the edges (Fig. 49a), sternum black with dark brown color bands at apical edges (Fig. 49b), pygidial plate two connected segments, black, dense long black setae erected downwards (Fig. 49c).
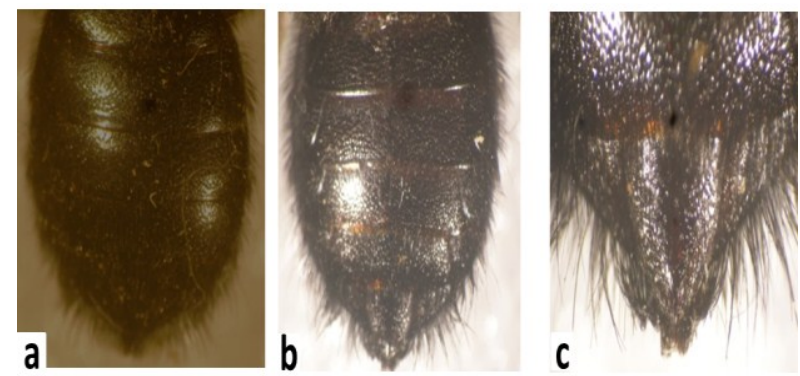

Figure (49). a-Tergum, b-Sternum, c- Pygidial plate of (q) Xylocopa iris.

\section{Xylocopa (Copoxyla) iris}

(Christ, 1791) $\widehat{\sigma}$

Examined material: $\widehat{\jmath} 3$ Albaida, 3.7.2018. $17 \mathrm{~mm}$ body length (Fig. 50).

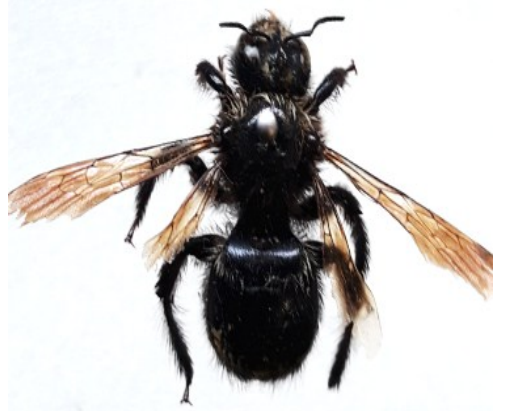

Figure (50). Adult of $(\overbrace{}^{\Uparrow})$ Xylocopa iris.

Head: semi-rounded, slightly narrower than the body, black, densely punctate, dense long dark brown setae, vertex simple curved to the inside with dense long light brown setae erected to the outside (Fig. 51).

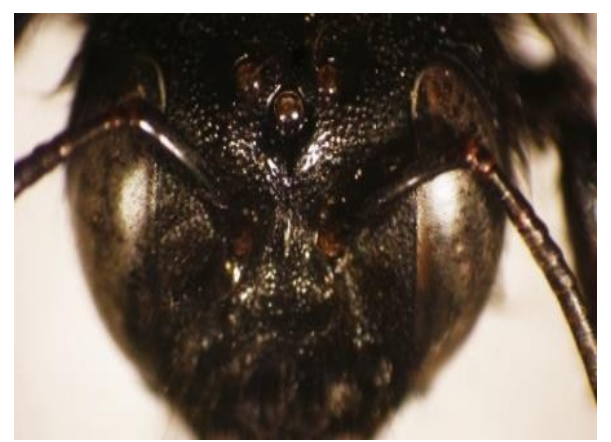

Figure (51). The head of ( $\overbrace{}^{\Uparrow})$ Xylocopa iris.

Compound eyes: bright black, dense long black setae between compound eyes, paraocular carina clear, genal area wide.

Ocelli: triangle shape, dark brown, the lateral ocelli less than the height level of compound eyes, the median ocellus aligned with frontal line (Fig. 52).

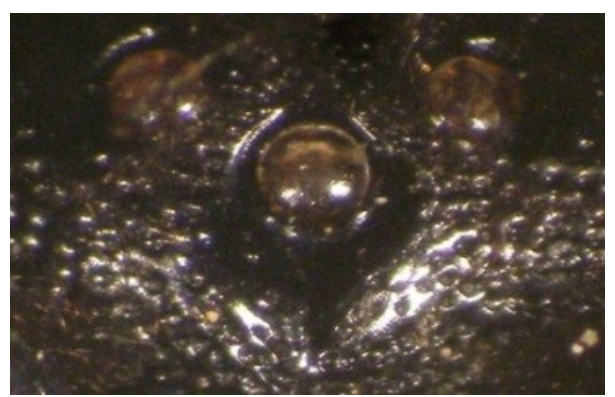

Figure (52). Ocelli of (ð̋) Xylocopa iris.

Clypeus: black, the end of apical thick, dark brown, little long dark brown setae, black projection at the middle of the base, densely punctate, dense long black setae on the surface.

Mandibles: rectangular, tridentate at apex, black with black lope at the connecting area with the malar area, acetabular groove clear, outer groove clear, condylar groove clear, densely punctate (Fig. 53). 


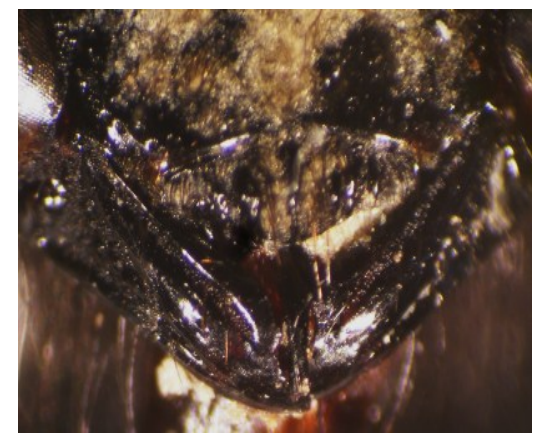

Figure (53). Mandible of ( $₫)$ Xylocopa iris.

Labrum: semi-circular shape with triangular extension at the middle, black.

Mouthparts: long, galea dark brown, glossa light brown with dense light brown setae (Fig. $54)$.

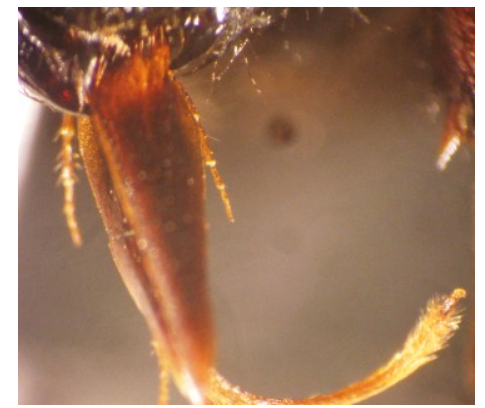

Figure (54). Mouthparts of ( $\left.\zeta^{\wedge}\right)$ Xylocopa iris. Antennae: thirteen segments, antennal socket dark brown, scape long, rectangular, black, pedicel short, rounded, black, the apical edges of scape and pedicel dark brown, flagellum eleven segments, black, the first flagellomere longer than the rest of the other flagellomeres, narrower at the base, wider at the apical, black and the apical edge dark brown, the other ten flagellomeres equal in shape and size, black, the terminal segment of antennae in sharp form (Fig. 55).

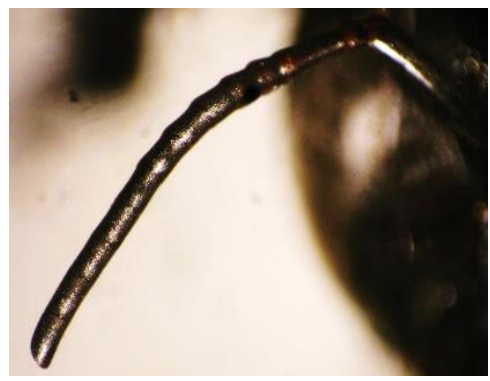

Figure (55). Antennae of ( $\lesssim)$ Xylocopa iris.

Thorax: width across thorax $5 \mathrm{~mm}$, prothorax larger than mesothorax and metathorax, black, dense long black setae, apical edge of prothorax with dense long light brown setae, densely punctate, tegula clear, large, black (Fig. 56).

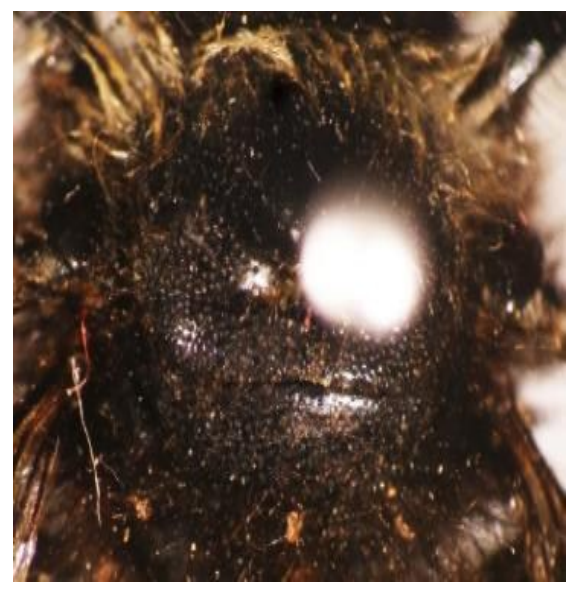

Figure (56). Thorax of (ð) Xylocopa iris.

Wings: forewings length $14 \mathrm{~mm}$, dark brown, the veins darker brown, vein $\mathrm{Sc}+\mathrm{R}$ black, marginal cell long and wide, the apical of marginal cell not jointed with costa vein, three submarginal cells, $2 \mathrm{smc}$ smaller than $1 \mathrm{smc}$ and $3 \mathrm{smc}, 3 \mathrm{smc}$ larger than $1 \mathrm{smc}$ and $2 \mathrm{smc}$, vein $1 \mathrm{rs}-\mathrm{m}$ with the same line vein $1 \mathrm{~m}-\mathrm{cu}$, vein 2 rs$\mathrm{m}$ curved outward, vein $2 \mathrm{~m}$-cu meets median vein opposite third submarginal cell, basal vein slightly curved, the lower end meeting the longitudinal vein at an acute angle (Fig. 57a), jugal lobe of hindwing very short, much less than half the length of the vannal lobe and not reaching anywhere near as far as vein closing cubital cell (Fig. 57b).
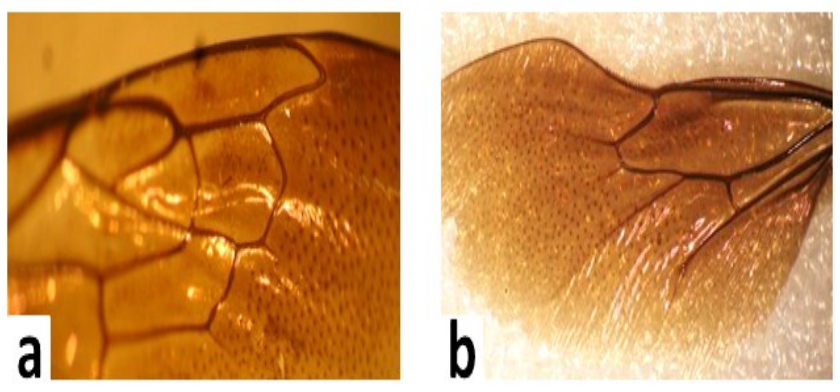

Figure (57). a- Forewings, b- Hindwings of (ð) Xylocopa iris.

Legs: coxa cylindrical has an extension, black with dense long black setae, trochanter 
narrower at the base, wider at the apical, black with dense long black setae, femur wider at the base, narrower at the apical, black with dense long black setae erected downwards, tibial rectangular, long, black with dense long black setae erected downwards, tibial spur one on each leg, ciliated, forelegs light brown, thicker than tibial spur of midlegs and hind legs, tibial spur of midlegs and hind legs dark brown, thick and longer than tibial spur of forelegs, tarsus five segments on each leg, basitarsus longer than mediotarsus and distitarsus, black with dense long black setae erected downwards, mediotarsus three segments equal in shape and size, dark brown with dense long black setae erected downwards, distitarsus longer than mediotarsus, narrower at the base, wider at the apical, dark brown with little dark brown setae (Fig. 58)

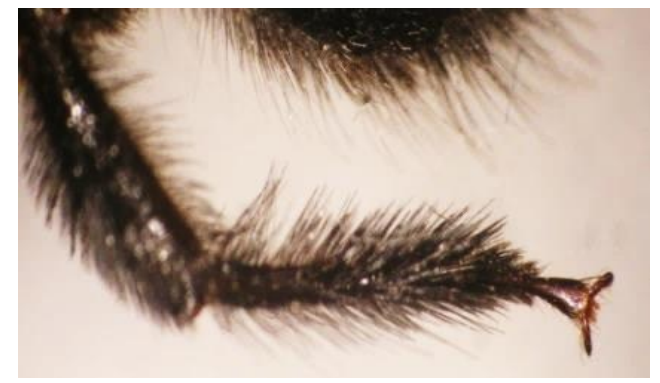

Figure (58). Hindleg of ( $\overbrace{}^{\Uparrow})$ Xylocopa iris.

Pair of elongated tarsal claws, branched at apical, the lateral longer than the internal one, the base dark brown, apical black, arolium with short yellow setae (Fig. 59).

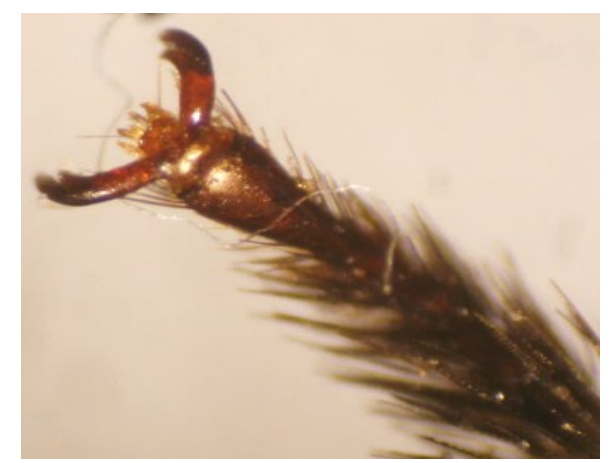

Figure (59). Tarsal claws of Xylocopa iris.
Abdomen: width across abdomen $6 \mathrm{~mm}$, seven segments, black with dark brown color bands at apical edges, tergum I with dense long light brown setae, terga from II to VII with dense long black setae, tergum II wider than the rest of the other terga, tergum VII semi-rounded shape, narrower than the rest of the other terga, densely punctate (Fig. 60a), sternum black with dense long black setae erected downwards (Fig. 60b).
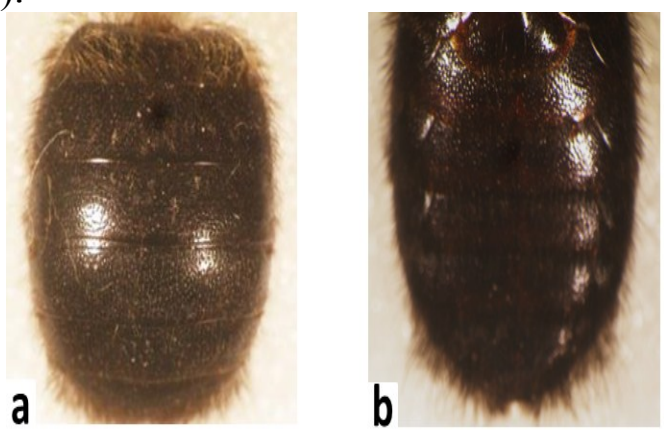

Figure (60). a- Tergum, b- Sternum of (ठ઼) Xylocopa iris

\section{ACKNOWLEDGEMENT}

We thank Georg Els, Stuart Robert NHM for their assistance in confirming identification of specimens. And special thanks to Michaël Terzo for identified Xylocopa amedaei.

\section{REFERENCES}

Cockerell, T. D. A. (1908). Some Bees Collected by Dr. FC Wellman, in West Africa.

Eardley, C. D. (1983). A taxonomic revision of the genus Xylocopa Latreille (Hymenoptera: Anthophoridae) in southern Africa.

Gerling, D., Velthuis, H., \& Hefetz, A. (1989). Bionomics of the large carpenter bees of the genus Xylocopa. Annual review of Entomology, 34(1), 163-190.

Hurd, P. D. (1963). A classification of the large carpenter bees (Xylocopini)(Hymenoptera: Apoidae). 
University of California Publications in Entomology, 29, 1-365.

Keasar, T. (2010). Large carpenter bees as agricultural pollinators. Psyche: $A$ Journal of Entomology, 2010.

Maa, T. (1970). revision of the subgenus Ctenoxylocopa (Hymenoptera: Anthophoridae). Pacific Insects.

Mawdsley, J., Harrison, J., \& Sithole, H. (2016). Natural history of a South African insect pollinator assemblage (Insecta: Coleoptera, Diptera, Hymenoptera, Lepidoptera): diagnostic notes, food web analysis and conservation recommendations. Journal of Natural History, 50(45-46), 28492879.

Michener, C. D. (2007). The bees of the world.

Minckley, R. L. (1998). A cladistic analysis and classification of the subgenera and genera of the large carpenter bees, tribe Xylocopini (Hymenoptera: Apidae).

Terzo M. \& Rasmont P. (2014). Atlas of the European Bees: genus Xylocopa. STEP Project, Atlas Hymenoptera, Mons, Gembloux.http://www.zoologie.umh.ac. be/hymenoptera/page.asp?ID=214

Warncke, K. (1982). Die holzbienen des vorderen orients (Hym., Apidae).

Zavattari, E. (1934). Prodromo della fauna della Libia: pubblicato sotto gli auspici del Ministero delle colonie e della $R$. Universitá di Pavia. Tipografia già cooperativa. 


\title{
التعريف والوصف المورفولوجي لانواع النحل جنس Xylocopidae: Hymenoptera) Xylocopa) في
}

\section{شمال شرق ليبيا}

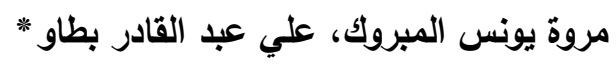 \\ قسم علم الحيوان، كلية العلوم؛ جامعة عمر الدختار، البيضاء-ليييا \\ تاريخ الاستلام: 25 أغسطس2019 / تاريخ القبول: 30 ديسمبر 2019 \\ https://doi.org/10.54172/mjsc.v34i4.165:Doi
}

المستخلص : تستهدف هذه الدراسة تعريف ووصف الصفات المورفولوجية التصنيفية لانواع النحل جنس Xylocopa في شمال

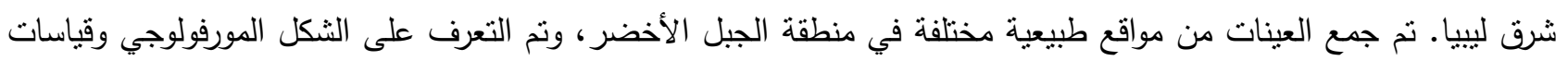

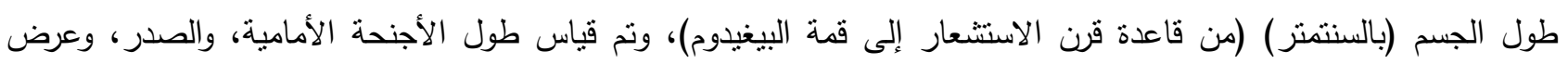

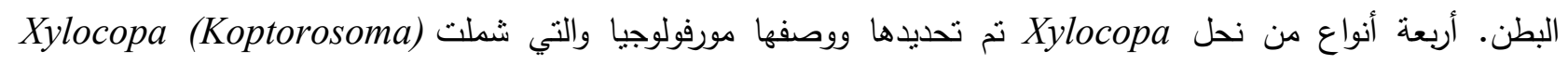
pubescens Spinola, 1838, Xylocopa (Proxylocopa) olivieri Lepeletir 1841, Xylocopa (Rhysoxylocopa), amedaei Lepeletir, 1841, Xylocopa iris (Christ, 1791). بها تتوع حيوي من أنواع Xylocop وكنلك على أهمية الدراسة المورفولوجية لتزويدنا بالمعلومات التصنيفية المهمة. الكلمات المفتاحية: Xylocopidae Xylocopa؛ الثكل الظاهري؛ تعريف؛ لييبا. 